\title{
Surface Changes in an Original and Activated Bentonite
}

\author{
Juan de Dios Lopez-Gonzalez ${ }^{2}$ and Victor R. Deitz
}

\begin{abstract}
The physical adsorption of nitrogen was used to study a bentonite activated by a treatment with hydrochloric acid. The Brunauer-Emmett-Teller equation, the Hüttig equation, and a so-called "summation" equation were used in the calculation of the surface areas available to nitrogen. The changes in surface area at different temperatures have been related to the quantity of adsorbed water and the amount of constitutional hydroxyl groups. The surface area is a measure of only the external boundary (nonswelling surface) of the bentonite, and this is increased significantly by the activation process. The ratio of surface areas (activated to original) is about four. A maximum in the surface area was found to exist when all of the adsorbed water was eliminated. However, the surface area decreased with the removal of water formed by decomposition of the constitutional hydroxyl groups. Chemical analyses, dehydration curves, thermal differential analyses, X-ray patterns, and electron micrographs were employed to characterize the materials.
\end{abstract}

\section{Introduction}

Bentonite $[1]^{3}$ is generally defined as a rock that contains 75 percent or more of the crystalline claylike minerals montmorillonite or beidellite [ 2 to 7 ]. The proportions of impurities in samples from many locations have been studied by Ross and Hendricks [4]. The minerals of this group show a wide variability in chemical composition, but there is very little change in the crystalline structure as shown by Werry, Ross, and Kerr [9], Gruner [10], Marshall [11], Holzner [12], Kelley and Jenny [13], etc. The unique behavior of bentonite is evident from the number of specific properties that have been related to its crystal structure $[6,8,9]$.

Acid treatments of bentonites significantly change some of the specific properties of interest in industrial processes. If the acid is at relatively low concentration (about 0.1 to $0.01 N$ ), the exchangeable cations are replaced by hydrogen ions. If the acid concentration is increased, there is a partial chemical solution of the crystal structure. The extent of the dissolving action depends upon the concentration and nature of the acid, temperature, reaction time, and the ratio of the two reactants.

The decolorizing action and the efficiency of many clay-cracking catalysts, which generally have very specific properties, increase in general with the amount of hydrogen ions present on the surface [14]. Recent studies [15] have shown that the catalytic action of silica-alumina gels can also be related to the hydrogen ions present on the surface. Small amounts of basic compounds (calcium, potassium, nitrogen, etc.) have a poisoning influence on the cracking activity of catalysts. Mills, Boedeker, and Oblad [16] assume that the "active hydrogen ions" are eliminated from the catalyst during cracking, and as a result the cracking activity is decreased.

Water contained in bentonites also plays a very important role in their adsorbent properties in nonaqueous media. This water, generally determined

1 This investigation was sponsored as a joint research project undertaken by the Bone Char Research Project, Inc. and the National Bureau of Standards.

${ }_{2}^{2}$ Guest worker holding a fellowship of the Consejo Superior de Investigaciones Cientificas, Spain.

3 Figures in brackets indicate the literature references at the end of this paper. by loss of weight after heat treatments, is in part adsorbed water and in part due to the decomposition of the constitutional hydroxyl groups $[18,19]$. Both forms, when retained in the bentonite, play an important role in the surface activity. For example, the amount of the dye, Red Sudan B, adsorbed by bentonites from benzene solutions was shown by Castro and Gonzalez [17] to change notably with moisture content.

In view of the aforementioned adsorption properties of bentonite, it was considered of interest to measure the changes in suriace area brought about by a treatment with hydrochloric acid and to ascertain the influence of the residual water on the total surface. The acid treatment of the bentonite is first described. The original material and the product formed were characterized briefly by chemical and physical-chemical methods in current use. The data for the adsorption of nitrogen at liquid-nitrogen temperature are then presented and these results correlated with surface area and the probable structure of the acid-treated bentonite.

\section{Acid Activation of the Bentonite Sample}

\subsection{Preparation}

A commercial sample of bentonite ${ }^{4}$ was passed through a U. S. No. 140 sieve in order to eliminate particles greater than about $0.1 \mathrm{~mm}$ in diameter. Five hundred grams of this bentonite were refluxed with 5 liters of hydrochloric acid ( $10 \%$ by weight) for 2 hours. The acid-treated bentonite was washed with distilled water until the wash water was free from chloride ions, and the final product was dried for about 40 hours at $105^{\circ} \mathrm{C}$ and kept in a desiccator. It has been previously shown [17] that a bentonite treated by this method had the highest adsorptive capacity for the dye Red Sudan $B$ when the concentration of the acid used for activation was about 10 percent by weight. At the lower or higher acid concentrations, a product of less adsorptive capacity was formed.

${ }^{4}$ Identified as a southern bentonite (Panther Creek, Miss.). 


\subsection{Chemical Composition}

The chemical composition ${ }^{5}$ of the bentonite was determined before and after the acid treatment. The components removed were determined in the filtrate after acid treatment. The results, given in table 1, show that a large part of the aluminum, iron, and magnesium in the original crystal structure was removed. All calcium ions were removed, as was to be expected, because it is a readily exchangeable cation. The silica originally combined with the cations removed was practically insoluble in the hydrochloric acid solution and remained in the residual material. It is known that the crystalline forms of silica are not appreciably soluble under treatment with sodium carbonate [20]. Therefore, the noncrystalline silica was determined as follows: $1 \mathrm{~g}$ of the residual material was treated with $100 \mathrm{ml}$ of water containing $5 \mathrm{~g}$ of sodium carbonate and boiled for 5 minutes; the filtrate was analyzed for silica.

TABLE 1. Chemical analysis of bentonite

[Sample dried at $110^{\circ} \mathrm{C}$ ]

\begin{tabular}{|c|c|c|c|}
\hline Components & $\begin{array}{c}\text { Original } \\
\text { bentonite }\end{array}$ & $\begin{array}{l}\text { Activated } \\
\text { material a }\end{array}$ & $\begin{array}{c}\text { Original } \\
\text { component } \\
\text { removed } \\
\text { by activa- } \\
\text { tion }\end{array}$ \\
\hline $\begin{array}{l}\mathrm{SiO}_{2} \\
\mathrm{Al}_{2} \mathrm{O}_{3} \\
\mathrm{Fe}_{2} \mathrm{O}_{3} \\
\mathrm{MgO} \\
\mathrm{CaO} \\
\text { Ignition loss }\end{array}$ & $\left\{\begin{array}{c}\text { Percent by } \\
\text { weight } \\
\text { b } 0.84 \\
\text { o } 59.64 \\
21.35 \\
6.49 \\
3.01 \\
0.90 \\
6.99\end{array}\right.$ & $\begin{array}{c}\text { Percent by } \\
\text { weight } \\
\text { b } 30.1 \\
\text { c } 47.7 \\
12.7 \\
3.5 \\
0.6 \\
.0 \\
5.2\end{array}$ & $\begin{array}{r}\text { Percent } \\
\mathrm{d} 0.1 \\
54.5 \\
58.9 \\
83.5 \\
100.0 \\
\end{array}$ \\
\hline Total & 99. 22 & 99.8 & ... \\
\hline $\begin{array}{l}\text { Adsorbed water } \\
\text { Water from constitutional oH } \\
\text { groups. }\end{array}$ & $\begin{array}{r}2.79 \\
\text { f } 4.20\end{array}$ & $\begin{array}{r}2.4 \\
12.8\end{array}$ & - n \\
\hline
\end{tabular}

a Loss in weight on activation, $21 \%$.

b Amounts of "nonerystalline" silica.

- Corresponding amounts of silica in the silicate structure of the bentonite plus a small part which was detected by the X-ray diffraction patterns to be quartz

$\mathrm{d}$ Silica found in the solution after the acid treatment.

e Defined as the water realized in heating the sample at $350^{\circ} \mathrm{C}$ to constant weight.

1 Found from dehydration curves (fig. 1) and from ignition losses.

The amount of "noncrystalline" silica, that is, silica soluble in a boiling 5 -percent solution of sodium carbonate, was very small $(0.84 \%)$ in the original bentonite but was large $(30.1 \%)$ in the acid-treated material. Apparently, by removing the aluminum, iron, and magnesium, the original silicate is converted into some amorphous form of silica. Table 1 shows that the ignition loss is smaller in the acidtreated material. "The latter will henceforth be designated as the "activated material".

\subsection{Dehydration Curves}

The curves in figure 1 were obtained by the method of Kelley, et al. [19, 21]. The loss in weight

\footnotetext{
${ }_{5}^{5}$ The authors are indebted to R. B. Rudy and H. I. Feinsten of the Bureau for some of the chemical analyses.
}

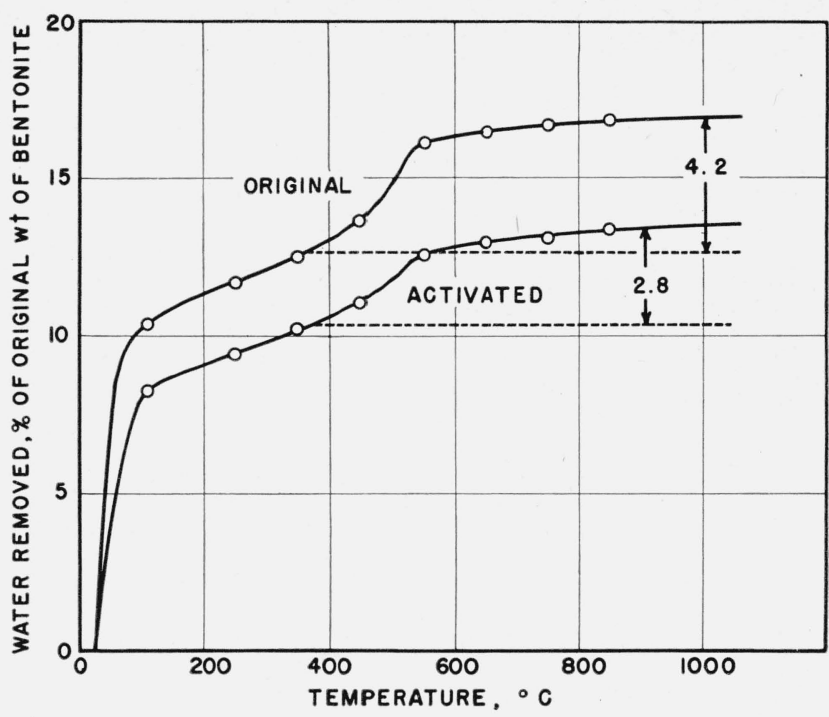

FIgURE 1. Dehydration curves for the original and activated bentonites.

of the sample on heating was attributed to the loss of moisture. Both graphs were characterized by a definite change in curvature, beginning at about $300^{\circ} \mathrm{C}$. Above $550^{\circ} \mathrm{C}$ the amount of water removed changed only slightly with increase of temperature. The similarity in the shapes of the two curves indicates that the activated material has a structure similar to that of unactivated bentonite. The breaks in the curves at $300^{\circ} \mathrm{C}$ correspond to a water loss of approximately 4.2 percent and 2.8 percent in the original and activated samples, respectively. These figures were calculated with respect to the final weight of the sample after heating to $850{ }^{\circ} \mathrm{C}$. According to many other investigators, these values correspond to the water formed in the decomposition of hydroxyl groups in the bentonite. Therefore, the activated product on this basis would contain only two-thirds of the constitutional hydroxyl groups contained in the original bentonite.

\subsection{Differential Thermal Analysis}

Figure 2 shows differential thermal analyses for the original and activated samples. ${ }^{6}$ These results represent the rate of heating a sample as compared with a sample of indifferent material recorded as a function of the temperatures at which differences in the rates of heating occur [22]. Two principal minima were observed, one near $200^{\circ}$ and the other near $700^{\circ} \mathrm{C}$. The depths of the minima are smaller in the activated bentonite. Apparently, the adsorbed water is retained more weakly in the activated material than in the original bentonite. The slight minimum at $690^{\circ} \mathrm{C}$ for the activated material indicates the removal of a large part of constitutional hydroxyl groups as a result of the acid activation process.

${ }^{6}$ The authors are indebted to E. S. Newman of the Bureau for the experimenta results. 


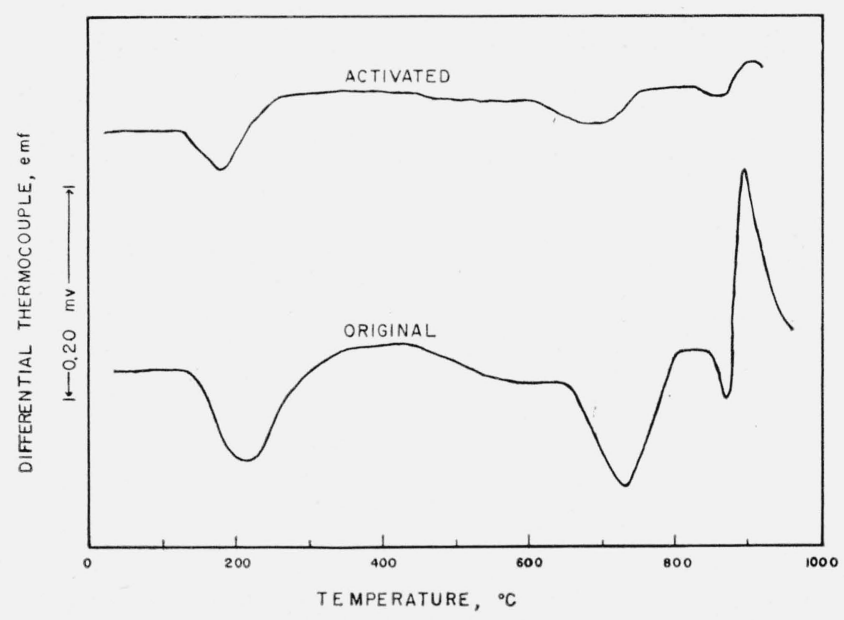

Figure 2. Differential thermal analysis curves of the original and activated bentonite.

\subsection{X-Ray Diffraction}

X-ray diffraction patterns ${ }^{7}$ were taken of the original bentonite after it was heated at $350^{\circ} \mathrm{C}$ and of the acid-activated material after it was heated at $250^{\circ} \mathrm{C}$. These are given in figure 3 . The X-ray diffraction patterns of the resulting material showed a great intensity for the $(h k 0)$ reflections when compared with the $(00 l)$ reflections. This indicates that the bentonite heated to $350^{\circ}$ had a poor crystallographic development in the direction of the $c$ axis.

In the activated material, beated only at $250^{\circ} \mathrm{C}$, a total destruction of the basal reflections was observed. This could indicate a total destruction of the montmorillonitic structure by the acid treatment. Previous work [33] has shown that a heat treatment of bentonite at $250^{\circ} \mathrm{C}$ produces only minor changes in structure when compared with that produced by the acid treatment. However, the persistence of the $(h k 0)$ reflections in the activated bentonite indicates that the planar arrangement

${ }_{7}$ The authors are indebted to the Constitution and Microstructure Section of the Bureau for the X-ray patterns and the electron micrographs.

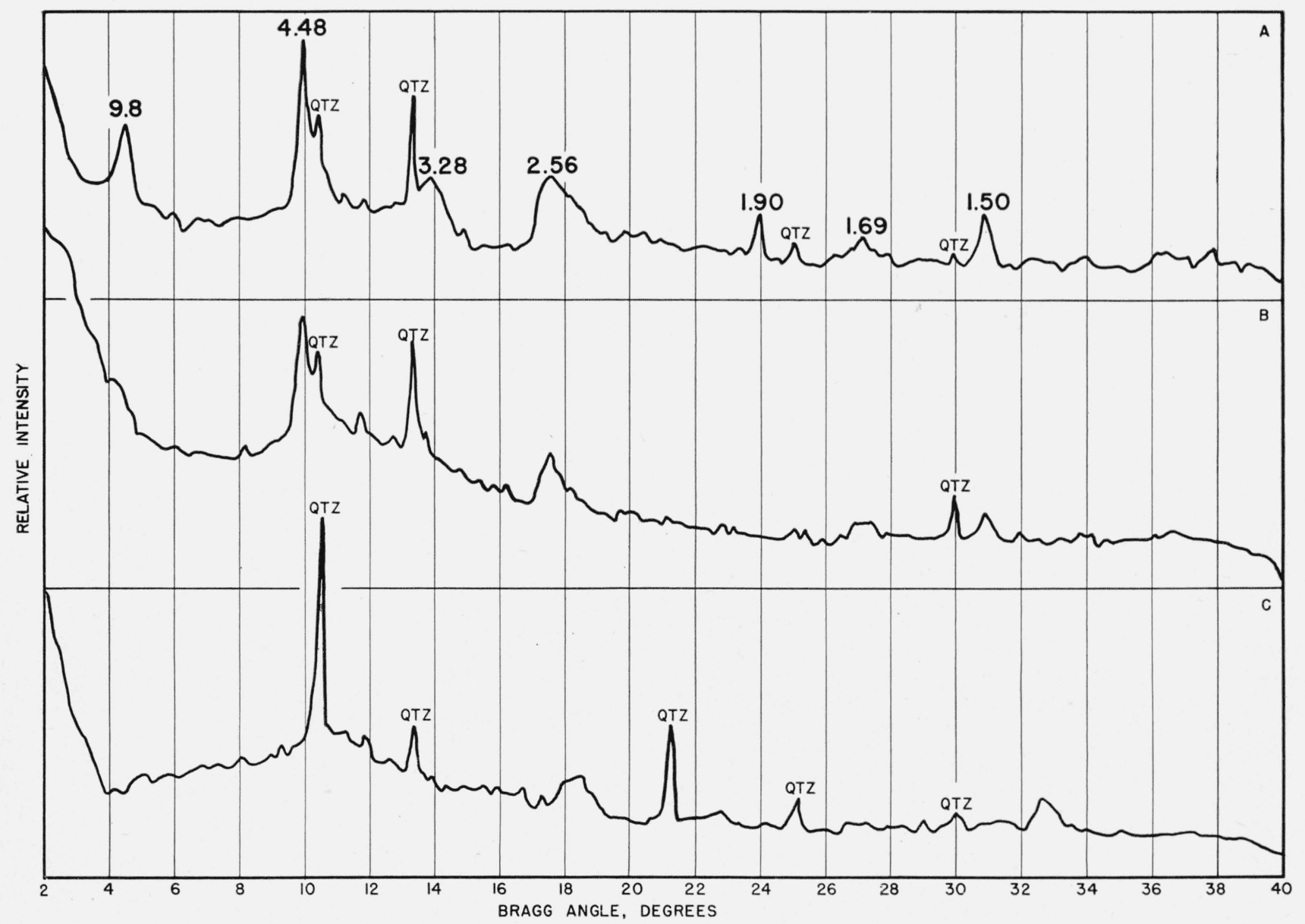

FIGURE 3. X-ray diffraction patterns for the original and activated bentonite.

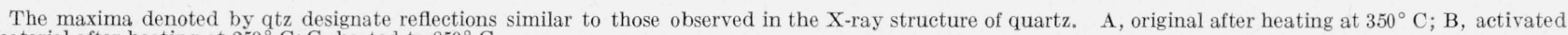
material after heating at $250^{\circ} \mathrm{C}$; $\mathrm{C}$, heated to $850^{\circ} \mathrm{C}$. 
with respect to $c$ axis is poor, and the destruction of relatively few layers in each crystal is enough to show an apparent total disorder with respect to basal reflections. This disorder can be attributed to the presence of the residual non-crystalline silica between the layers of the montmorillonite.

X-ray diffraction patterns showed that the structure of both original bentonite and activated material changed completely when heated at $850^{\circ} \mathrm{C}$.

\subsection{Electron-microscope pictures}

Samples of the original bentonite and activated material were prepared for electron micrographs with butyl alcohol as a dispersing agent, after practically complete removal of the adsorbed water. The micrographs do not show differences between the two samples, either in particle shape or in size. This indicates that the noncrystalline silica, formed by the action of hydrochloric acid, remains between the residual layers of the bentonite where it cannot be detected.

\section{Adsorption of Nitrogen and the Calculation of $V_{m}$}

\subsection{Data}

The adsorption isotherms of nitrogen at $-195^{\circ} \mathrm{C}$ were determined with a conventional B. E. T. apparatus [23]. The temperature of the liquid nitrogen was ascertained by means of a nitrogen vapor pressure thermometer. The results for the original bentonite are given in table 2 and those for the activated bentonite in table 3 . Samples were evacuated before the adsorption measurements for periods of 18 hours at each of the following temperatures: $110^{\circ}, 250^{\circ}, 350^{\circ}$, and $450^{\circ} \mathrm{C}$. Other samples contained in porcelain dishes were heated at $550^{\circ}, 650^{\circ}, 750^{\circ}$, and $850^{\circ} \mathrm{C}$ in an electric furnace. These were transferred to the adsorption apparatus and evacuated for 18 hours at $450^{\circ} \mathrm{C}$ before the adsorption measurements. Desorption measurements were also made in a number of cases.

In order to adsorb nitrogen in the presence of large amounts of water in the bentonite, fresh samples were exposed to water vapor, placed in the adsorption bulb, and then evacuated at either $-78^{\circ}$ or $+25^{\circ} \mathrm{C}$ for a period of 45 minutes. The samples were then cooled to $-195^{\circ} \mathrm{C}$ for the nitrogen adsorption measurements. A portion of the wet sample was analysed for moisture content.

Typical adsorption isotherms are given in figure 4. These correspond to the type II isotherms of Brunauer's classification [23]. In all cases the activated bentonite (curves $\left.1^{\prime}, 2^{\prime}, 3^{\prime}, 4^{\prime}\right)$ adsorbed more nitrogen than the original (curves $1,2,3,4$ ) after comparable evacuation temperatures. The desorption experiments indicated that hysteresis phenomena were rather small with the original bentonite but were greater in the activated material, in agreement with its greater content of particle voids. The volume of gas adsorbed at a given pressure increased with the temperature of evacuation of the samples up
TABLE 2. Adsorption of nitrogen at $-195^{\circ} \mathrm{C}$.

Original bentonite

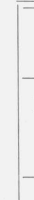

\begin{tabular}{|c|c|c|c|}
\hline$p$ & V & $p$ & $V$ \\
\hline \multicolumn{2}{|c|}{$\begin{array}{c}\text { Evacuation at } \\
-78 \mathrm{C} \text { for } 45 \\
\min \end{array}$} & \multicolumn{2}{|c|}{$\begin{array}{l}\text { Evacuation } \\
\text { after } 550^{\circ} \mathrm{C} \\
\text { for } 18 \mathrm{hr}\end{array}$} \\
\hline \multirow{7}{*}{$\begin{array}{r}56.9 \\
114.7 \\
196.5 \\
260.6 \\
679.9 \\
748.7 \\
762.3 \\
768.2 \\
773.6\end{array}$} & \multirow{7}{*}{$\begin{array}{r}0.48 \\
.48 \\
.49 \\
.48 \\
.88 \\
2.29 \\
3.67 \\
5.51 \\
6.86\end{array}$} & 43.8 & 17.4 \\
\hline & & 119.2 & 20.6 \\
\hline & & 172.7 & 22.3 \\
\hline & & 233.3 & 24.1 \\
\hline & & & \\
\hline & & & \\
\hline & & & \\
\hline & & \multirow{2}{*}{\multicolumn{2}{|c|}{$\begin{array}{l}\text { Evacuation } \\
\text { after } 650^{\circ} \mathrm{C} \\
\text { for } 18 \mathrm{hr}\end{array}$}} \\
\hline \multirow{2}{*}{\multicolumn{2}{|c|}{$\begin{array}{c}\text { Evacuation at } \\
25^{\circ} \mathrm{C} \text { for } 45 \\
\text { min }\end{array}$}} & & \\
\hline & & 33.1 & 14.0 \\
\hline 44.6 & 5.6 & $\begin{array}{l}170.7 \\
229.0\end{array}$ & $\begin{array}{l}18.7 \\
20.4\end{array}$ \\
\hline $\begin{array}{l}4 . .0 \\
69.1\end{array}$ & $\begin{array}{l}0.0 \\
6.2\end{array}$ & 288.8 & 22.2 \\
\hline 112.7 & 6.9 & 348.6 & 24.3 \\
\hline 171.7 & 7.9 & 506.9 & 31.1 \\
\hline 264. 2 & 9.4 & 643.2 & 42.5 \\
\hline 452.9 & 13.4 & 692.8 & 52.3 \\
\hline 570.2 & 17.7 & 713.7 & 60.9 \\
\hline 713.6 & 36.5 & 626.4 & ${ }^{a} 46.3$ \\
\hline 737.3 & 46.3 & 342.6 & ${ }^{a} 24.2$ \\
\hline 748.6 & 59.9 & 132.8 & $a 17.6$ \\
\hline 295.5 & 99.9 & 59.5 & ${ }^{a} 15.3$ \\
\hline 73.8 & ${ }^{a} 6.1$ & & \\
\hline 24.9 & ${ }^{a} 5.0$ & & \\
\hline \multirow{2}{*}{\multicolumn{2}{|c|}{$\begin{array}{l}\text { Evacuation at } \\
110^{\circ} \mathrm{C} \text { for } 18 \mathrm{hr}\end{array}$}} & \multirow{3}{*}{\multicolumn{2}{|c|}{$\begin{array}{l}\text { Evacuation } \\
\text { after } 750^{\circ} \mathrm{C} \\
\text { for } 18 \mathrm{hr}\end{array}$}} \\
\hline & & & \\
\hline \multirow{8}{*}{$\begin{array}{r}6.3 \\
23.4 \\
184.9 \\
327.1 \\
478.4 \\
612.0 \\
372.0 \\
185.0 \\
69.4\end{array}$} & \multirow{8}{*}{$\begin{array}{r}4.7 \\
18.2 \\
25.1 \\
30.2 \\
36.5 \\
46.3 \\
{ }^{a} 33.8 \\
{ }^{a} 25.3 \\
{ }^{a} 21.4\end{array}$} & & \\
\hline & & & \\
\hline & & $\begin{array}{l}12.5 \\
74.6\end{array}$ & $\begin{array}{l}2.9 \\
6.0\end{array}$ \\
\hline & & 130.8 & 6.9 \\
\hline & & $\begin{array}{l}190.8 \\
190.9\end{array}$ & $\begin{array}{l}7.9 \\
7.7\end{array}$ \\
\hline & & 273.7 & 9.0 \\
\hline & & 442.5 & 12.6 \\
\hline & & 566.5 & 16.7 \\
\hline \multirow{2}{*}{\multicolumn{2}{|c|}{$\begin{array}{l}\text { Evacuation at } \\
250^{\circ} \mathrm{C} \text { for } 18 \mathrm{hr}\end{array}$}} & $\begin{array}{l}112.2 \\
731.3\end{array}$ & $\begin{array}{l}34.8 \\
40.6\end{array}$ \\
\hline & & 710.1 & a37. 4 \\
\hline & & 499. 2 & ${ }^{a} 16.5$ \\
\hline$m m \mathrm{Hg}$ & & 233.4 & ${ }^{a} 7.1$ \\
\hline 42.1 & 19. 0 & $\begin{array}{l}74.9 \\
35.2\end{array}$ & $\begin{array}{l}{ }^{2} 4.7 \\
{ }_{a} 3.9\end{array}$ \\
\hline $\begin{array}{l}178.0 \\
222.1\end{array}$ & $\begin{array}{l}23.7 \\
25.0\end{array}$ & & \\
\hline $\begin{array}{l}222.1 \\
271.6\end{array}$ & $\begin{array}{l}20.0 \\
26.5\end{array}$ & & \\
\hline \multicolumn{2}{|c|}{$\begin{array}{l}\text { Evacuation at } \\
350^{\circ} \mathrm{C} \text { for } 18 \mathrm{hr}\end{array}$} & \multirow{2}{*}{\multicolumn{2}{|c|}{$\begin{array}{l}\text { Evacuation } \\
\text { after } 850^{\circ} \mathrm{C} \\
\text { for } 18 \mathrm{hr}\end{array}$}} \\
\hline \multirow{5}{*}{$\begin{array}{c}m m \mathrm{Hg} \\
85.2 \\
177.5 \\
210.8 \\
253.3\end{array}$} & \multirow{5}{*}{$\begin{array}{l}m l / g \\
22.8 \\
25.7 \\
26.8 \\
28.2\end{array}$} & & \\
\hline & & & \\
\hline & & 102.9 & \\
\hline & & 152.0 & .11 \\
\hline & & 216.8 & 11 \\
\hline \multirow{3}{*}{\multicolumn{2}{|c|}{$\begin{array}{l}\text { Evacuation at } \\
450^{\circ} \mathrm{C} \text { for } 18 \mathrm{hr}\end{array}$}} & & \\
\hline & & 740.0 & .35 \\
\hline & & 766. 2 & 1. 10 \\
\hline & & 729.4 & a. 39 \\
\hline $\begin{array}{l}49.9 \\
84.4\end{array}$ & $\begin{array}{ll}20 . \\
202\end{array}$ & & \\
\hline $\begin{array}{r}84.4 \\
135.3\end{array}$ & $\begin{array}{l}23.0 \\
23.7\end{array}$ & & \\
\hline 217.0 & 26.2 & & \\
\hline
\end{tabular}

${ }^{a}$ Desorption points.

to a maximum and then decreased. For example, curve $1^{\prime}$ of figure 4 was obtained after an initial evacuation at $25^{\circ} \mathrm{C}$, curve $2^{\prime}$ after evacuation at $110^{\circ} \mathrm{C}$, curve $3^{\prime}$ after evacuation upon treatment at $650^{\circ} \mathrm{C}$, and curve $4^{\prime}$ after evacuation upon treatment at $750^{\circ} \mathrm{C}$.
TABLE 3. Adsorption of nitrogen at $-195^{\circ} \mathrm{C}$.

Activated bentonite

\begin{tabular}{|c|c|c|c|}
\hline$p$ & $V$ & $p$ & $V$ \\
\hline \multicolumn{2}{|c|}{$\begin{array}{c}\text { Evacuation at } \\
-78^{\circ} \mathrm{C}\end{array}$} & \multicolumn{2}{|c|}{$\begin{array}{c}\text { Evacuation at } \\
450^{\circ} \mathrm{C}\end{array}$} \\
\hline 16.8 & 2.2 & 57.6 & 63.7 \\
\hline 69.4 & 3.3 & 114.7 & 73.4 \\
\hline 135.8 & 4.0 & 198.4 & 85.8 \\
\hline 188.7 & 4. 4 & 237.8 & 89.6 \\
\hline 248.3 & 4. 9 & & \\
\hline 413.0 & 6.6 & & \\
\hline $\begin{array}{l}638.9 \\
704.7\end{array}$ & $\begin{array}{l}12.5 \\
12.2\end{array}$ & \multirow{2}{*}{\multicolumn{2}{|c|}{$\begin{array}{l}\text { Evacuation } \\
\text { after } 550^{\circ} \mathrm{C}\end{array}$}} \\
\hline 733.6 & $20 . \overline{5}$ & & \\
\hline $\begin{array}{l}752.2 \\
763.4\end{array}$ & 23. 6 & & \\
\hline 711.0 & $\begin{array}{l}a \\
a \\
a\end{array}$ & 6.4 & 27.5 \\
\hline 646.2 & ${ }^{a} 16.4$ & 88.0 & 60.3 \\
\hline 520.3 & ${ }^{a} 10.1$ & 173.9 & 72.2 \\
\hline 296.5 & ${ }^{a} 5.3$ & 233.6 & 80.2 \\
\hline 132.3 & ${ }^{a} 3.9$ & & \\
\hline \multicolumn{2}{|c|}{$\begin{array}{c}\text { Evacuation at } \\
25^{\circ} \mathrm{C}\end{array}$} & \multicolumn{2}{|c|}{$\begin{array}{l}\text { Evacuation } \\
\text { after } 650^{\circ} \mathrm{C}\end{array}$} \\
\hline 38.6 & 19.3 & 3.2 & 18.1 \\
\hline 73.6 & 23.3 & 20.9 & 41. 6 \\
\hline 128.8 & 27.7 & 119.6 & 59. 1 \\
\hline 206.1 & 33.0 & 185.1 & 67.5 \\
\hline 280.5 & 38.6 & 281.2 & 80.3 \\
\hline 373.5 & 47.6 & 408.0 & 102.4 \\
\hline 480.3 & 61.9 & 520.1 & 131. 6 \\
\hline 568.7 & 84.3 & 589.4 & 153.9 \\
\hline 639.9 & 111.9 & 625.5 & 173.0 \\
\hline 678.6 & 130.0 & 649.8 & 190.7 \\
\hline 700.3 & 142.5 & 612.3 & ${ }^{a} 178.5$ \\
\hline 720.1 & 154. 7 & 502.5 & ${ }^{a} 139.5$ \\
\hline 452.0 & ${ }^{a} 75.1$ & 391.2 & ${ }^{a} 104.5$ \\
\hline \multicolumn{2}{|c|}{$\begin{array}{c}\text { Evacuation at } \\
110^{\circ} \mathrm{C}\end{array}$} & 101.4 & a56. 6 \\
\hline $\begin{array}{l}7.3 \\
8.8\end{array}$ & 10. 1 & \multicolumn{2}{|c|}{$\begin{array}{l}\text { Evacuation } \\
\text { after } 750^{\circ} \mathrm{C}\end{array}$} \\
\hline 82.5 & 69.8 & & \\
\hline 243.2 & 94.5 & & \\
\hline 397.2 & 123. 2 & 19.6 & 33.3 \\
\hline 510.3 & 155.3 & 161.5 & 53.4 \\
\hline 357.9 & ${ }^{a} 119.3$ & 210.6 & 58.8 \\
\hline 235.3 & a93.1 & 247.2 & 63.2 \\
\hline 116.1 & $a 76.6$ & 292.4 & 69. 1 \\
\hline \multirow{2}{*}{\multicolumn{2}{|c|}{$\begin{array}{c}\text { Evacuation at } \\
250^{\circ} \mathrm{C}\end{array}$}} & $\begin{array}{l}510.9 \\
575.3\end{array}$ & $\begin{array}{l}\text { 110. } 0 \\
133.9\end{array}$ \\
\hline & & 616.9 & 151.5 \\
\hline & & 528.0 & ${ }^{a} 128.1$ \\
\hline$m m \mathrm{Hg}$ & $\mathrm{ml} / \mathrm{g}$ & $\begin{array}{l}428.7 \\
330.3\end{array}$ & $\begin{array}{l}\text { a98. } 7 \\
\text { a.4. } 6\end{array}$ \\
\hline $\begin{array}{r}10.2 \\
104.0\end{array}$ & 76.4 & $\begin{array}{l}212.8 \\
212.0\end{array}$ & a.58. 9 \\
\hline 167.2 & 86.1 & & \\
\hline 212.4 & 93.0 & & \\
\hline \multicolumn{2}{|c|}{$\begin{array}{l}\text { Evacuation at } \\
350^{\circ} \mathrm{C}\end{array}$} & \multicolumn{2}{|c|}{$\begin{array}{l}\text { Evacuation } \\
\text { after } 850^{\circ} \mathrm{C}\end{array}$} \\
\hline$m m \mathrm{Hg}$ & $\mathrm{ml} / \mathrm{g}$ & 65.7 & 17.4 \\
\hline 34.7 & 61.1 & 119.2 & 20.2 \\
\hline 162.8 & 83.5 & 165.7 & 22.3 \\
\hline 215.6 & 91.4 & 249.2 & 26.0 \\
\hline 265.5 & 99.2 & & \\
\hline
\end{tabular}

$a$ Desorption points. 


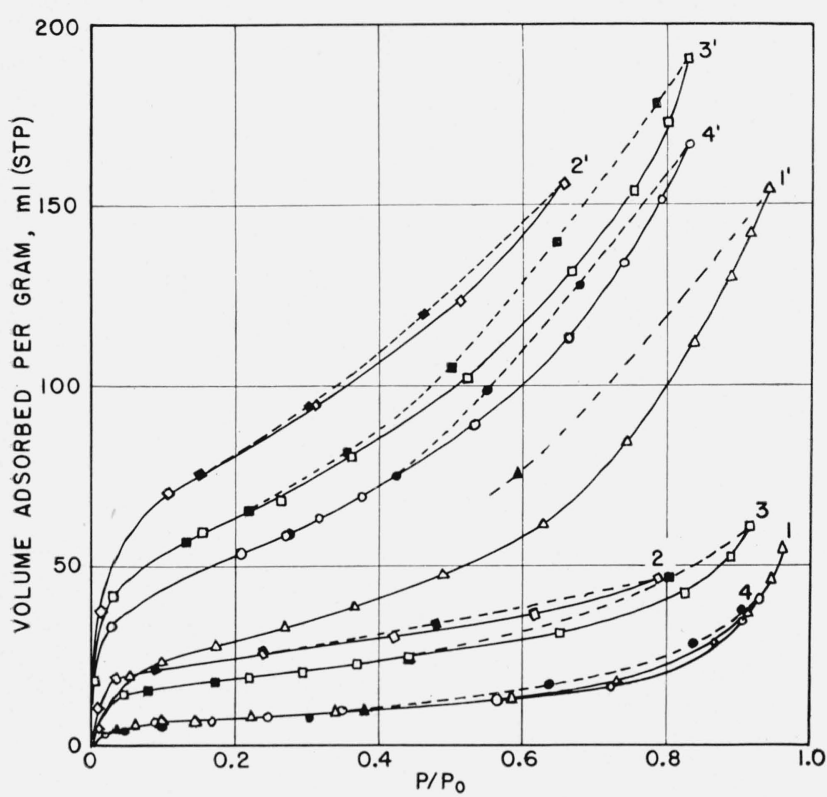

Figure 4. Adsorption isotherms of nitrogen at $-195^{\circ} \mathrm{C}$ on the original and activated bentonite, after evacuation at different temperatures: numbers $1,2,3$, and 4 correspond to the original bentonite evacuated at $25^{\circ}, 110^{\circ}, 650^{\circ}$, and $750^{\circ} \mathrm{C}$, respectively; numbers $1^{\prime}, 2^{\prime}, 3^{\prime}$, and $4^{\prime}$ correspond to the activated bentonite evacuated at $25^{\circ}, 110^{\circ}, 650^{\circ}$, and $750^{\circ} \mathrm{C}$, respectively.

\subsection{Determination of $V_{m}$}

In current theories of physical adsorption, $V_{m}$ is defined as the volume of adsorbed gas, calculated at standard temperature and pressure (STP), which covers the available surface with a single layer of molecules. The value of $V_{m}$ has been determined by using a number of different equations for adsorption isotherms at $78^{\circ} \mathrm{K}$.

The free-surface isotherm for multimolecular adsorption derived by Brunauer, Emmett, and Teller [24] may be written according to eq 1:

$$
\frac{p}{V\left(p_{0}-p\right)}=\frac{1}{c V_{m}}+\left(\frac{c-1}{c V_{m}}\right) \frac{p}{p_{0}}
$$

where $p$ is the pressure in equilibrium with the adsorbent, $\mathrm{p}_{0}$ the pressure in equilibrium with liquid nitrogen, $V$ the volume of gas adsorbed, and $c$ is a constant related to the heat of adsorption. According to this equation a plot of $p /\left[V\left(p_{0}-p\right)\right]$ as a function of $p / p_{0}$ should be a straight line. Actually, the required linearity was observed only for values of $p / p_{0}$ less than about 0.5 for the majority of isotherms. As an example, data are plotted in figure 5 for the case in which both samples of bentonite were evacuated at a temperature of $25^{\circ} \mathrm{C}$ preliminary to the measurements.

The isotherm proposed by Hüttig [25, 26] may be written

$$
\frac{p}{V p_{0}}\left[1+\frac{p}{p_{0}}\right]=\frac{1}{c V_{m}}+\left(\frac{1}{V_{m}}\right) \frac{p}{p_{0}} .
$$

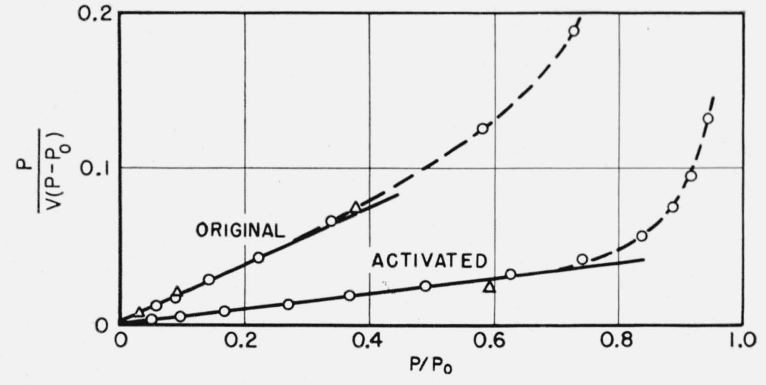

Figure 5. Brunauer-Emmett-Teller linear plot for nitrogen adsorbed on the original and activated bentonite evacuated at $25^{\circ} \mathrm{C}$, in accordance with $\mathrm{eq} 1$.

o, Adsorption; $\triangle$, desorption,

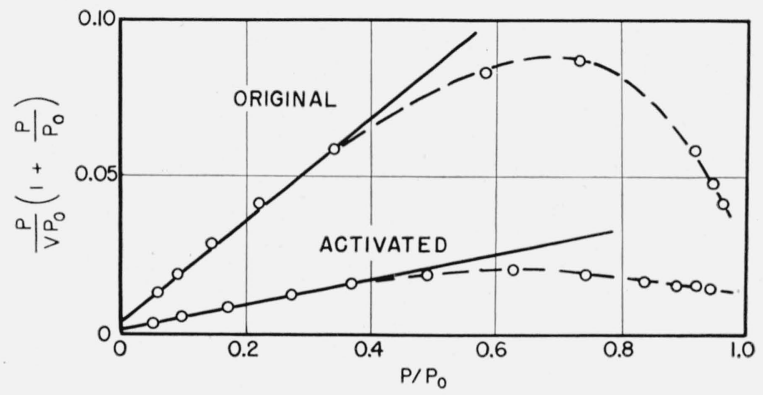

FIGURE 6. Hüttig linear plot for adsorbed nitrogen on the original and activated bentonite evacuated at $25^{\circ} \mathrm{C}$, in accordance with eq 2.

A straight line should be obtained when the left side of eq 2 is plotted as a function of $p / p_{0}$. When this equation was applied to the data for bentonite, the deviation from linearity was observed for values of $p / p_{0}$ greater than about 0.4 . A typical plot of these data is shown in figure 6 . In general, the data do not conform to the Hüttig equation as well as they do to the B. E. T. equation.

A simple relationship was observed that yielded a linear plot for values of $p / p_{0}$ as high as 0.8 . This relation is obtained by adding eq 1 and 2 to give eq 3 :

$$
\frac{p}{2 V p_{0}}\left[\frac{p_{0}}{p_{0}-p}+\frac{p_{0}+p}{p_{0}}\right]=\frac{1}{c V_{m}}+\left(\frac{c-1 / 2}{c V_{m}}\right)\left[\frac{p}{p_{0}}\right] \text {. }
$$

In this case a straight line is to be expected on plotting the left side of eq 3 as a function of $p / p_{0}$. A typical plot is given in figure 7. A straight line was obtained up to a value of $p / p_{0}$ of 0.8 .

It should be noted that the improved equation does not contain any constants other than those in the original B. E. 'T. theory. The fact that the straightline relationship holds over a greater range of pressure is an advantage for the determination of the value of $V_{m}$. The fact that the adsorption data yields a straight line over a greater pressure range when plotted according to eq 3 is a necessary but not sufficient criterion for the correctness of the equation. 


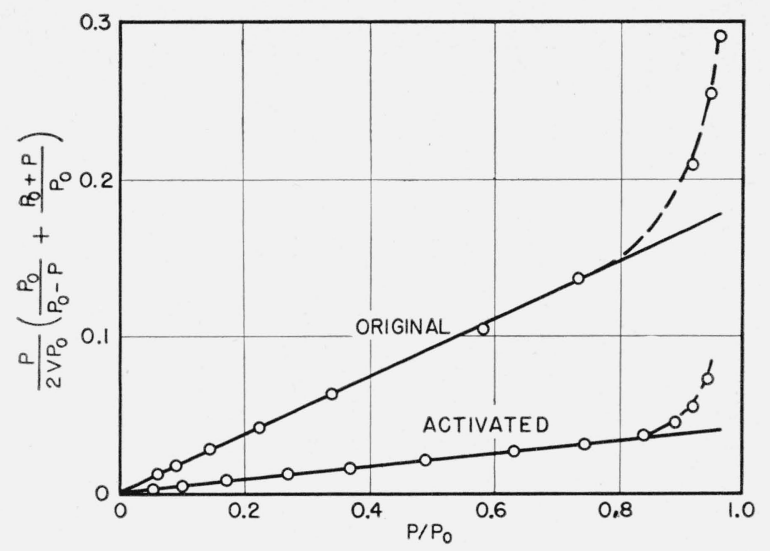

FIGURE 7. Linear plot of the "summation" equation for adsorbed nitrogen on the original and activated bentonite evacuated at $25^{\circ} \mathrm{C}$, in accordance with eq 3.

There are other important requirements for a theory of multimolecular adsorption, but these will not be discussed in this paper. ${ }^{8}$

\section{Variation of $V_{m}$ with Water Content of Bentonites}

Table 4 lists the values of $V_{m}$ when calculated according to eq. 1, 2, and 3 and the corresponding

TABLE 4. Values of $V_{m}$ and surface areas of original and activated bentonite calculated by B. E. T., Hüttig, and the proposed summation ( $\Sigma$ ) equation.

\begin{tabular}{|c|c|c|c|c|c|c|}
\hline \multirow{2}{*}{$\begin{array}{c}\text { Evacuation } \\
\text { Temp. }\end{array}$} & \multicolumn{3}{|c|}{$V_{m}$} & \multicolumn{3}{|c|}{$m^{2} / g$ a } \\
\hline & B.E.T. & Hüttig & $\Sigma$ & B.E.T. & Hüttig & $\Sigma$ \\
\hline \multicolumn{7}{|c|}{ Original bentonite } \\
\hline $\begin{array}{r}{ }^{\circ} \mathrm{C} \\
-78 \\
25 \\
110 \\
250 \\
350 \\
450 \\
550 \\
650 \\
750 \\
850\end{array}$ & $\begin{array}{c}0.35 \\
6.3 \\
19.2 \\
17.8 \\
19.1 \\
20.0 \\
17.5 \\
14.6 \\
6.81 \\
0.051\end{array}$ & $\begin{array}{c}0.37 \\
7.0 \\
20.9 \\
20.0 \\
21.4 \\
21.0 \\
18.8 \\
17.6 \\
6.8 \\
0.052\end{array}$ & $\begin{array}{l}0.36 \\
6.6 \\
19.3 \\
18.7 \\
20.1 \\
20.5 \\
17.9 \\
15.2 \\
6.4 \\
0.051\end{array}$ & $\begin{array}{c}1.5 \\
27.7 \\
83.8 \\
77.8 \\
83.5 \\
87.3 \\
76.4 \\
63.6 \\
26.5 \\
0.22\end{array}$ & $\begin{array}{c}1.6 \\
30.6 \\
91.3 \\
87.4 \\
93.5 \\
91.9 \\
82.3 \\
76.8 \\
29.7 \\
0.23\end{array}$ & $\begin{array}{c}1.6 \\
28.7 \\
84.5 \\
81.8 \\
87.9 \\
89.5 \\
78.1 \\
66.5 \\
27.9 \\
0.22\end{array}$ \\
\hline \multicolumn{7}{|c|}{ Activated bentonite } \\
\hline $\begin{array}{r}-78 \\
25 \\
110 \\
250 \\
350 \\
450 \\
550 \\
650 \\
750 \\
850\end{array}$ & $\begin{array}{r}3.5 \\
24.8 \\
65.7 \\
70.4 \\
67.2 \\
65.8 \\
57.0 \\
52.1 \\
43.9 \\
18.1\end{array}$ & $\begin{array}{r}3.7 \\
28.7 \\
72.4 \\
75.8 \\
74.7 \\
72.9 \\
61.6 \\
61.3 \\
57.1 \\
20.3\end{array}$ & $\begin{array}{r}3.7 \\
27.4 \\
68.7 \\
72.8 \\
71.0 \\
69.1 \\
59.5 \\
57.1 \\
45.3 \\
19.3\end{array}$ & $\begin{array}{r}15 \\
108 \\
287 \\
308 \\
294 \\
288 \\
249 \\
228 \\
192 \\
79\end{array}$ & $\begin{array}{r}16 \\
125 \\
317 \\
329 \\
327 \\
319 \\
269 \\
268 \\
250 \\
89\end{array}$ & $\begin{array}{r}16 \\
120 \\
300 \\
318 \\
310 \\
302 \\
260 \\
250 \\
198 \\
85\end{array}$ \\
\hline
\end{tabular}

a The surface area values are referred to samples dried at $110^{\circ} \mathrm{C}$ and the crosssectional area of the adsorbed nitrogen molecule at of $16.1 \mathrm{~A}^{2}$.

8 The theory of Hüttig for multimolecular adsorption, recently discussed by Ross [26], Ferguson and Barret [27], and by Hüttig himself [28] has been critized Hill [29]. He has shown that Hütig's equation cannot be obtained from the B. E. T. Model without violation of statistical thermodynamical principles. Hill points out that the B. E. T. Model results in too low a free energy relative to the liquid state, and that Hüttig's treatment leads to a free energy that is too high [30].

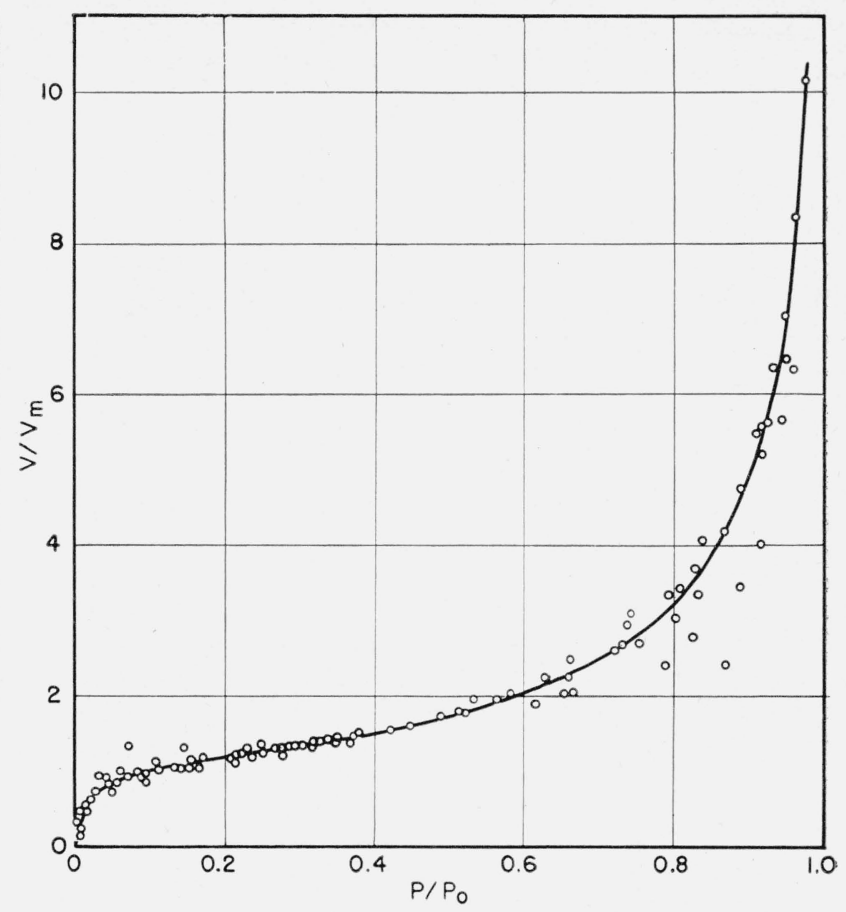

Figure 8. Adsorption isotherms of nitrogen at $-195^{\circ} \mathrm{C}$ on the original and activated bentonite evacuated at 10 different temperatures, reduced to unit surface.

surface areas. It can be seen that the results according to eq 3 [the "summation" equation] are always between those derived form the B. E. T. and Hüttig equations. The question arises as to which value gives the best approximation. For the purposes of a surface area determination it may be noted that average deviation of the B.E.T. value from that of the summation equation is usually less than 10 percent.

The value of $V_{m}$ from eq 3 is intermediate between the values from eq 1 and 2 , as shown in table 4 . The three equations were also applied to many different adsorbents (bone chars, graphon, silica gel, kaolin, etc.), and the values of $V_{m}$ were calculated. The uncertainty in $V_{m}$ due to the uncertainty in drawing the best straight line is small compared to the uncertainties in the packing of the nitrogen molecules in the adsorbed layers. For comparing surface areas of the same type of materials, it is recommended that $V_{m}$ for nitrogen be determined according to eq 3 .

In figure 8 is presented a plot of $V / V_{m}$ for all the data as a function of $p / p_{0}$. The close superposition of the data is striking and demonstrates that the volumes adsorbed are directly proportional to the surface area.

\subsection{Areas After Preliminary Temperature Treatment}

The temperature at which the initial evacuation of the sample was made has considerable influence on the resulting surface area. This is shown graphically in figure 9 . In the case of the original bentonite, the surface area changed little when the tempera- 


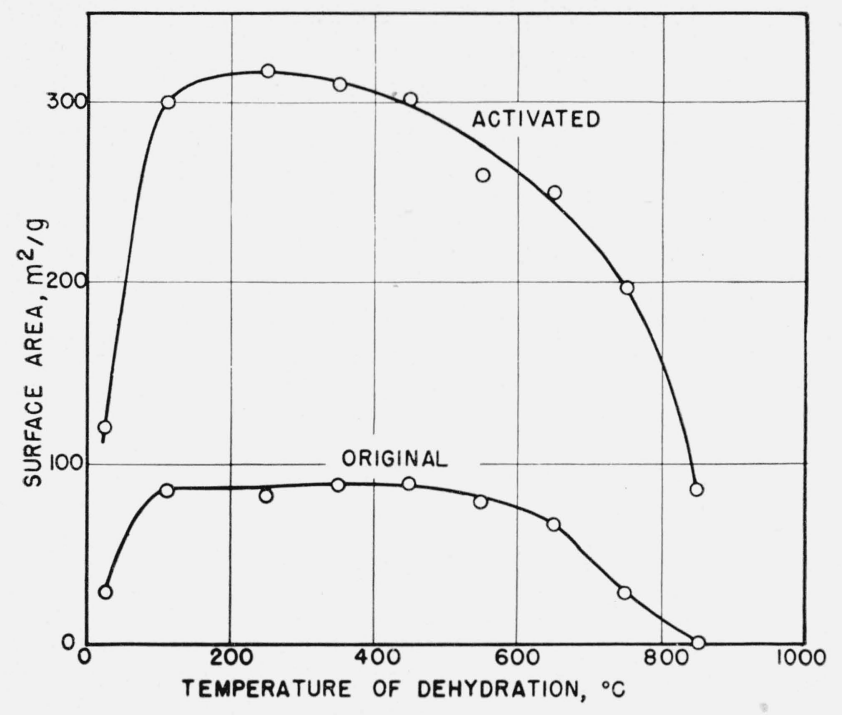

Figure 9. Surface area of the original bentonite and activated material as a function of the temperature of evacuation.

ture of evacuation was between $100^{\circ}$ and $500^{\circ} \mathrm{C}$. When higher temperatures were employed, the surface area declined steadily and reached a very small value at $850^{\circ} \mathrm{C}$. In contrast, the acid-treated bentonite attained a maximum surface area of almost four times the original area after heating at $250^{\circ}$ to $350^{\circ} \mathrm{C}$. The maximum for the activated sample was sensitive to temperature, and the area began to fall off appreciably at higher temperatures in the range where there was little change in the area of the original bentonite.

\subsection{Areas After Preliminary Water Addition}

The relations between the surface areas and the residual moisture retained by the bentonites were studied. Samples containing large quantities of moisture were obtained by exposure to water vapor in a closed container. Samples containing less moisture than that in the initial sample (dried to constant weight at $110^{\circ} \mathrm{C}$ ) were prepared by a heat treatment at the elevated temperatures previously mentioned.

It has been noted that the adsorber water in bentonite [21] may be considered to be expelled completely at about $350^{\circ} \mathrm{C}$ without any significant decomposition of the constitutional hydroxyl groups. Therefore, when the moisture content was referred to the constant weight of the samples at $350^{\circ} \mathrm{C}$, it was possible to compare changes in surface area with the quantity of adsorbed water, and with the extent of the decomposition of the constitutional hydroxyl groups. The results are plotted in figure 10. The surface area of the original bentonite decreased continuously with increase of adsorbed water from a maximum of 89 to $1.6 \mathrm{~m}^{2} / \mathrm{g}$; the latter value is for a sample containing 30.6 percent of moisture (see curve A). Furthermore, the surface area decreased with loss of the water derived from the decomposition of the constitutional hydroxyl

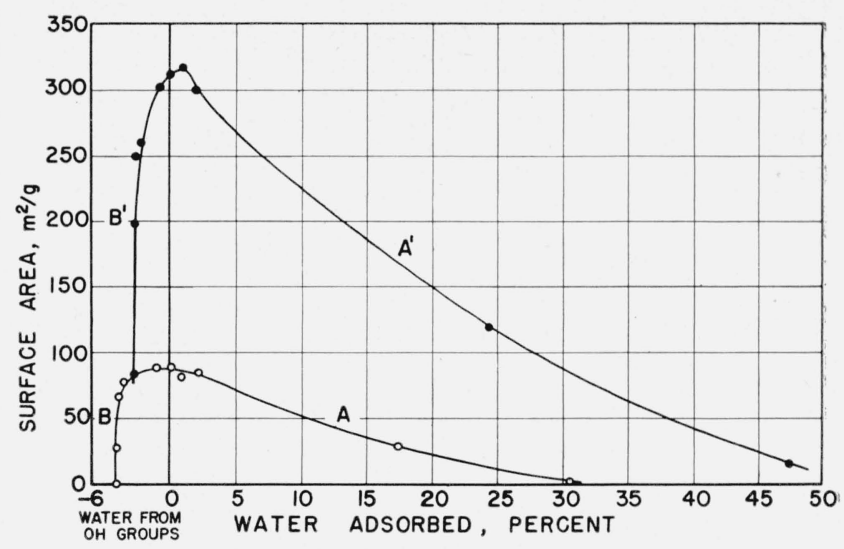

Figure 10. Surface area of the original bentonite and activated material as a function of the amount of adsorbed water and constitutional hydroxyl groups.

$\mathrm{A}$ and $\mathrm{B}$ are for original samples of bentonite and $\mathrm{A}^{\prime}$ and $\mathrm{B}^{\prime}$ for activated. material.

groups to a minimum value of $0.22 \mathrm{~m}^{2} / \mathrm{g}$ (see curve B) realized after heating the sample at $850^{\circ} \mathrm{C}$.

Similar behavior was found for the activated material. The surface area decreased from a maximum of 320 to $16 \mathrm{~m}^{2} / \mathrm{g}$ at a moisture content of 47.4 percent (see curve $\mathrm{A}^{\prime}$ ). When the activated material was heated (to constant weight), there was a progressive loss in surface area, the area decreasing to $85 \mathrm{~m}^{2} / \mathrm{g}$ after heating to $850^{\circ} \mathrm{C}$ (see curve $\mathrm{B}^{\prime}$ ).

\section{Discussion and Concluding Remarks}

The acid treatment of the bentonite employed destroys a large part of its crystal structure by removing aluminum, magnesium, and iron. The chemical analyses, dehydration curves, differential thermal analyses, X-ray diffraction patterns, and electron microscope picture indicate that the acidtreated bentonite contains a part of the original montmorillonitic structure.

After removal of aluminum, magnesium, and iron from the crystal structure, a residue of silica remains in the activated product. From the X-ray patterns. and electron microscope picture, it seems most probable that this noncrystalline silica remains. chiefly between the residue crystal layers and proproduces a crystalline disorder with respect to the $c$ crystallographic axis.

From the intensity of the $(h k 0)$ reflections in the activated product, after heat treatment at $250^{\circ}$, it should be possible to estimate the amount of bentonite (after $350^{\circ} \mathrm{C}$ treatment) destroyed by the acid treatment, but the error in doing so is about 25 percent, due to several factors that will not be discussed in this paper. It is important to observe that the absorption of X-rays by the noncrystalline silica formed in the acid treatment results in diminished intensities of the reflections, and as a result could be interpreted as too low a percentage of residual montmorillonitic structure in the activated product. By comparison of the above-mentioned 
reflections, and taking also into consideration the chemical analyses, dehydration curves, and differential thermal analyses, it can be estimated that the residual montmorillonitic structure in the activated material is of the order of 50 to 70 percent.

The surface area available to nitrogen at $-195^{\circ} \mathrm{C}$ of the original dried bentonite $\left(85\right.$ to $\left.90 \mathrm{~m}^{2} / \mathrm{g}\right)$ is only the external surface (nonswelling surface). This corresponds favorably with the theoretical value given by Dyal and Hendricks [31]. This value corresponds to only 10 percent of the total surface when dispersed into structural single layers, and it has been given by these authors and by Vivaldi [32] as about $880 \mathrm{~m}^{2} / \mathrm{g}$. Therefore, nitrogen cannot be adsorbed to an appreciable extent between the swelling layers of the original bentonite containing moisture.

The surface area of the activated material after elimination of the adsorbed water at $250^{\circ}$ to $350^{\circ} \mathrm{C}$ is about $320 \mathrm{~m}^{2} / \mathrm{g}$. This value is smaller than the total theoretical value of $880 \mathrm{~m}^{2} / \mathrm{g}$ for the montmorillonite dispersed into structural single layers. Apparently, the acid destroys part of the layers and creates an open structure, which, in the dried material, is available to nitrogen to a larger extent than in the original bentonite.

The previous and the following considerations make it possible to suggest a simplified view of the reaction between the acid and the smallest particle of material having the properties of the bentonite. The crystalline particles of montmorillonite are composed of aggregates about 10 single structural layers. Let us assume that a particle of the final activated product contains about 60 percent by weight of the bentonite, the acid attack having destroyed four out of ten layers (see fig. 11). In the residual structure, the crystal fragments $A, B$, and $C$ do not necessarily have to be oriented parallel. The silica, produced during the acid attack, is insoluble and is retained in the residue, which now contains sufficiently large particle voids to permit the entrance of nitrogen into the spaces $a$ and $b$. Figure 11 shows that the area of the acid-treated material is three times that of the bentonite, approximately $250 \mathrm{~m}^{2} / \mathrm{g}$. Taking into account the loss in weight $(20 \%)$ as a result of acid treatment, the surface area per gram of the residue is $320 \mathrm{~m}^{2} / \mathrm{g}$. This compares favorably with that found experimentally ( 315 to $\left.320 \mathrm{~m}^{2} / \mathrm{g}\right)$.

In practice, the process of acid attack is probably much more complicated. The destruction of the crystal layers must take place according to some random distribution. The proposed simplified model can also account for the observed desorption isotherms. The hysteresis observed for the activated material is attributed to the formation of the small particle voids such as $a$ and $b$ in figure 11. Hysteresis was not appreciable in the original bentonite.

The decrease in surface area with increase of adsorbed water can be explained by an aggregation of the individual particles. This process would explain the decrease in surface area of the bentonite from $85 \mathrm{~m}^{2} / \mathrm{g}$ with no adsorbed water to $1.6 \mathrm{~m}^{2} / \mathrm{g}$ with about 31 percent of water. The same effect is shown in the activated material, where the surface area decreases from $320 \mathrm{~m}^{2} / \mathrm{g}$ with no adsorbed water to $16 \mathrm{~m}^{2} / \mathrm{g}$ with about 47 percent of adsorbed water. The larger amount of adsorbed water in the activated material can be anticipated in view of its "open" structure.

The maxima in surface areas were observed when all the adsorbed water was removed, that is, at $250^{\circ}$ to $350^{\circ} \mathrm{C}$. In the original bentonite, most of the external surface was lost between $650^{\circ}$ and $750^{\circ} \mathrm{C}$ after the majority of the constitutional hydroxyl groups had been driven off. In the acid-treated bentonite the surface area decreased appreciably at a temperature where the original bentonite showed little change. This behavior suggests that the more irregular structure of the activated material is less stable.

It appears possible to select a temperture in the heat treatment of a sample at which only adsorbed water is removed. This fact is very important, especially where acid-treated bentonite is to be used in applications that require the maximum in surface area. The heat treatment preliminary to use can be confined to temperatures where only adsorbed water is removed. These facts further emphasize the importance of temperature control when bentonite is heated in adsorbing and catalytic processes.

The authors acknowledge the helpiul suggestions of W. V. Loebenstein, F. G. Carpenter, and H. P. Freeman of this Bureau and S. B. Hendricks and J. M. Vivaldi of the Bureau of Plant Industry, U. S. Department of Agriculture.

\section{References}

[1] C. S. Ross and E. V. Shannon, J. Am. Ceram. Soc. 9, 77 (1926).

[2] C. W. Davis and H. C. Vacher, Bureau of Mines Tech. Paper 438 (1928).
ORIGINAL CRYSTAL

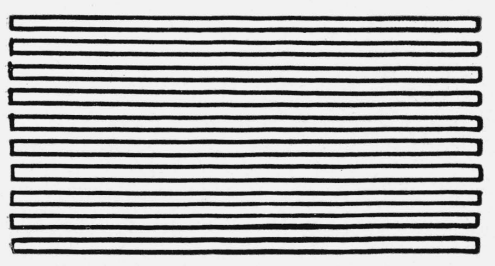

POSTULATED ACID ACTION

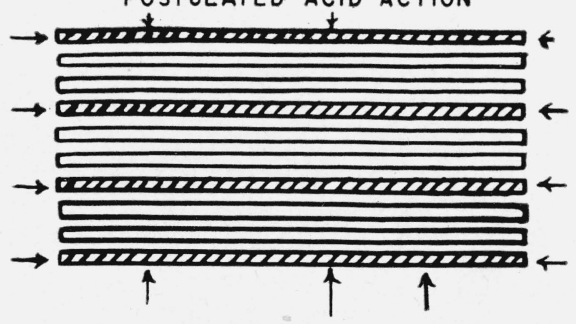

RESIDUE

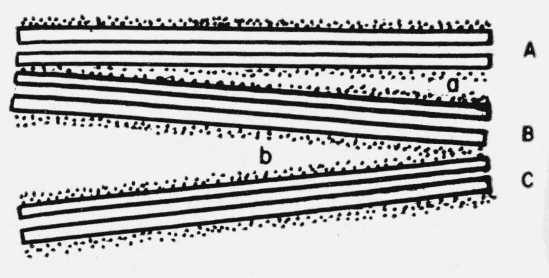

Figure 11. Probable mechanism for the acid attack on bentonite. 
[3] M. L. Jackson, Ph. D. Thesis, Univ. of Wisconsin (1939).

[4] C. S. Ross and S. B. Hendricks, U. S. Geol. Survey Professional Paper 205-B (1945).

[5] E. G. Rios and F. G. Garcia, Anales Edaf. Fisiol, Veg. T VII, III, 605 (1948).

[6] U. Hoffman, K. Endell, and D. Wilm, Z. Krist. 86A, 340 (1933).

[7] U. Hofmann and W. Vilke, Kolloid-Z. 78, 239 (1936).

[8] G. H. Edelman and J. Favejee, J. Krist. 102, 417 (1940).

[9] E. T. Wherry, C. S. Ross and P. F. Kerr, Colloid Symposium Annual 191 (1930).

[10] J. W. Gruner, Am. Mineral. 20, 475 (1935).

[11] C. E. Marshall, Z. Krist. 91A, 433 (1936).

[12] J. Holmer, Chem. Erde 9, 464 (1936).

[13] W. P. Kelley and H. Jenny, Soil Sci. 41, 367 (1936).

[14] C. L. Thomas, J. Hickey, and G. Stecker, Ind. Eng. Chem. 42, 866 (May 1950)

[15] T. H. Milliken, Jr., C. A. Mills, and A. G. Oblad, Faraday Soc. Discussion, No. 8, 279 (1950).

[16] G. A. Mills, A. R. Boedeker, and A. G. Oblad, J. Am. Chem. Soc. 72, 1554 (1950).

[17] A. Hoyos de Castro and J. deD. Lopez-Gonzalez, Anales Edaf. y Fisiol. Veg. 6, 623 (1950).

[18] J. Mering, Trans. Faraday Soc, 42B, 205 (1946).

[19] W. P. Kelley, H. Jenny, and S. M. Brown, Trans. Third Int. Congr. Soil Sci. 3, 84 (1935).
[20] C. S. Ross and S. B. Hendricks, U. S. Geol. Survey Professional Paper 205-B, p. 36 (1945).

[21] W. P. Kelley, H. Jenny, and S. M. Brown, Soil Sci. 41, 259 (1936).

[22] R. E. Grim and R. A. Rowland, Am. Mineral. 27, 746 to 761,801 to $818(1942)$.

[23] S. Brunauer, The adsorption of gases and vapors (Princeton Univ. Press, Princeton, N. J., 1943).

[24] S. Brunauer, P. H. Emmett, and E.'Teller, J. Am. Chem. Soc. 60, 309 (1938).

[25] G. F. Hüttig, Monatsh. 78, 177 (1948).

[26] S. Ross, J. Phys. Colloid Chem. 53, No. 3, 383 (1949).

[27] R. R. Ferguson and R. M. Barrer, Trans. Faraday Soc. 46, 400 (1950).

[28] G. F. Hüttig and O. Theimer, Kolloid-Z. 119, 69 to 73 (1950).

[29] T. L. Hill, J. Am. Chem. Soc. 72, 5347 (1950).

[30] T. L. Hill, private communication.

[31] R. S. Dyal and S. B. Hendricks, Soil Sci. 69, 421 to 432 $(1950)$.

[32] J. M. Vivaldi, private communication.

[33] F. G. Garcia, Anales de Fisica y Quimica (Spain) 45, 1183 to 1210 (Sept.-Oct. 1949).

Washington, January 8, 1952. 